\title{
Organizational and managerial mechanism of digitalization in a transport company
}

\author{
Irina Markaryan ${ }^{1, *}$ and Natalia Datsun 1 \\ 1 The Russian Law Academy of the Ministry of Justice of the Russian Federation (ARSJ - RLA \\ Ministry of Justice of Russia), st. Azovskaya, 2, bld. 1, Moscow, Russia
}

\begin{abstract}
The development of digital economy is to create market incentives, motivations, demand and needs for the use of digital technologies, products and services among transport companies, spheres of life, business and society for their efficiency, competitiveness and national development and welfare of the population. This article provides for the implementation of measures for the implementation of appropriate incentives for digitalization in the transport company, public and social spheres, awareness of existing challenges and tools for the development of digital infrastructure, acquisition of digital competencies by the staff of the transport company, as well as determines the critical areas and projects of digitalization, stimulation of the domestic market, use and consumption of digital technologies. The path to digital economy lies through the use and consumption of information, communication and digital technologies.
\end{abstract}

\section{Introduction}

Nowadays, the term digitalization has become common in the corporate world. Business leaders, speakers, governments and other economic actors often use it. Digitalization is important because it is part of business strategy.

Contrary to popular belief, digitalization affects not only transport industry companies. It affects all types of business, in all industries [2].

Nevertheless, the application of digitalization in practice is still not widespread in transport companies. The main problem is that companies lack knowledge of the strategy to be adopted to succeed in the digital age. Too often efforts make organizations even more vulnerable. However, the digital transformation offers huge opportunities for transport companies to remain competitive.

\section{Materials and methods}

To achieve the goal, the following methods were used: dialectical and abstract-logic, monographic, economic-statistical, graphic.

\footnotetext{
* Corresponding author: 2703 irina@ mail.ru
} 


\section{The main part}

Digitalization of an organization is a global transformation of a company that must go through its «value chain» [1].

Digitalization affects the company as a whole (distribution, customer experience, communication, business model, management, HR, production, etc.). [3]. For this reason, it should be viewed not as an activity or project, but as a complete and structural reorganization of the enterprise. Therefore, it is clearly of a strategic nature and should be included in the corporate strategy.

In the event that digitalization is not part of the corporate strategy, the risk is that it will not be consistent and will find itself in a mixed situation characterized by a scattering of efforts, leading to a reduction or disappearance of expected results.

The digital revolution is a fact. Thus, it is necessary to develop new strategies that include this phenomenon, which will allow in the first stage to develop together with the environment and in the second stage to create a competitive advantage [5].

Sustainable digitalization of a company is achieved through the simultaneous transformation of several categories and technologies. This applies in particular to the business model, company structure, human capital, processes, potential and skills, product and service offerings, stakeholder engagement and transformation gas pedals. This is a continuous process of improvement, as the digital strategy must be constantly adjusted to take advantage of new opportunities.

The collection of data and information, providing a clear and complete picture of the digital situation, allows an inventory of existing digital resources. Different organizational goals are then defined, highlighting existing opportunities. This first step concludes with the identification of key performance indicators for each digital resource.

An assessment of the existing digital ecosystem provides a clear picture of the state of digital activity. In particular, the organization is interested in the efficiency and contribution of digital resources, as well as in the digital maturity of the company, its position in comparison with competitors and ways to improve its digital efficiency.

Planning for new resources requires identifying additional assets needed to achieve goals. Identification of potential risks allows for proactive action [4].

The priority of strategic decisions and integration of digital resources include the creation of substrates, as well as determining the budget and the desired result.

Defining a plan of action for digital initiatives may lead not only to a re-engineering of the value chain, but also to a rethinking of the supply chain to take advantage of opportunities to develop innovative products and services.

Implementation of performance indicators helps to measure success and optimize results.

Monitoring and continuous improvement of user and client interfaces are key elements of a successful digital strategy. No business is profitable without its users and customers.

The choice of a digital strategy manager concerns the entire organization, as each department plays a vital role in digital success. The digital resource management model can consist of a centralized digital support unit, as well as a steering committee that includes each unit.

Understanding technical debt is essential from its impact on results and the efforts that need to be made to succeed in the digital age. This debt is the additional cost associated with improperly designed or managed digital operations.

Digital transformation is an important issue for transport and logistics: digitalization provides the industry with many opportunities to deal with increasing traffic flows [6].

The digital economy has been crucial to the successful development of transport and logistics companies for several years. For transport and logistics professionals, the challenges of digital transformation are manifold. 
Today, there is fierce competition in the field of transport. In recent years, traditional players have had to face the arrival of many companies whose offer is only available on the Internet. Thus, active participation in the digital transition has become important for business.

In the process of functioning of the logistics information system, different situations are possible that are typical for this system. Characteristic situations of digital interaction functioning on the example of LLC "Business Lines" are presented in Table 1.

Table 1. Characteristic situations of digital interaction functioning in LLC «Business Lines» [7].

\begin{tabular}{|c|c|c|l|}
\hline $\begin{array}{c}\text { Availability of } \\
\text { resources }\end{array}$ & $\begin{array}{c}\text { Access to } \\
\text { information }\end{array}$ & $\begin{array}{c}\text { Availability } \\
\text { of time }\end{array}$ & \multicolumn{1}{|c|}{ Characteristics of the situation } \\
\hline 0 & 0 & 0 & $\begin{array}{l}\text { The need for a radical approach to } \\
\text { logistics system activity }\end{array}$ \\
\hline 0 & 0 & 0 & $\begin{array}{l}\text { Attracting resources may not produce a } \\
\text { positive result }\end{array}$ \\
\hline 0 & 1 & 1 & $\begin{array}{l}\text { It is necessary to develop a program to } \\
\text { obtain the necessary information }\end{array}$ \\
\hline 0 & 0 & 1 & $\begin{array}{l}\text { The need to attract resources for the } \\
\text { system's operation }\end{array}$ \\
\hline 1 & 1 & 0 & $\begin{array}{l}\text { Availability of resources may not } \\
\text { produce a positive result }\end{array}$ \\
\hline 1 & 0 & 0 & $\begin{array}{l}\text { Need to engage subcontractors or use } \\
\text { secondary information }\end{array}$ \\
\hline 1 & 1 & 1 & $\begin{array}{l}\text { Planning of measures to ensure access } \\
\text { to necessary information }\end{array}$ \\
\hline 1 & 1 & $\begin{array}{l}\text { Ensuring normal functioning of the } \\
\text { system }\end{array}$ \\
\hline
\end{tabular}

To assess the effectiveness of digitalization LLC «Delovye Liniya» propose to apply methodological approaches based on replication of the process of goods movement from the very beginning - from ordering goods from the supplier to their sale to end users. Fig. 1 shows the general logistics information system of Delovoye Linii LLC. This scheme is identical for all branches.

Fig. 1 shows not only the places of receipt and movement of goods and information flows, but also the types of logistics that are responsible for this process. We believe that the cost values that occur in the logistics chain at the junction points determine the efficiency of the logistics chain. The total cost value allows us to draw a conclusion regarding the efficiency of the logistics system of Delovye Linii LLC as a whole. After all, the higher the costs at the junction points, the lower is the overall efficiency of the logistics system.

The forecasting process at Delovoye Linii LLC is as follows (fig. 2).

The basis of the forecasting process is a database containing information about current orders, orders for previous periods and receipts of these orders. This is facilitated by technical and information support, which is used by the heads of departments of LLC «Delovye Linii».

When performing an effective forecasting process using technical and information support, users fill in a database, which consists of a number of files with the necessary grouped information for the management of the central office and operational directors of the regions.

The choice of a prospective supplier in the conditions of the modern dynamic market of goods and services is one of the defining solutions in the implementation of the order for «Business Lines» LLC. Under these conditions, it is most appropriate to apply the so-called multi-criteria approach to the evaluation of suppliers and their further selection. Criteria of this approach should be systematized, that is, using a single database, by querying it you can get an answer to the desired question. After all, the data on the suppliers are marked at each delivery of goods, that is, the database selects a list of offered goods, their prices and discount conditions, entering information about how this supplier meets the conditions of the contract. 
Therefore, the use of information from the database information system to predict sales of goods and the choice of supplier plays an important role in the order of goods. After all, the manager of the central office or the head of any department, having the data, can effectively manage the supply system and track the location of the parcel or money transfer.

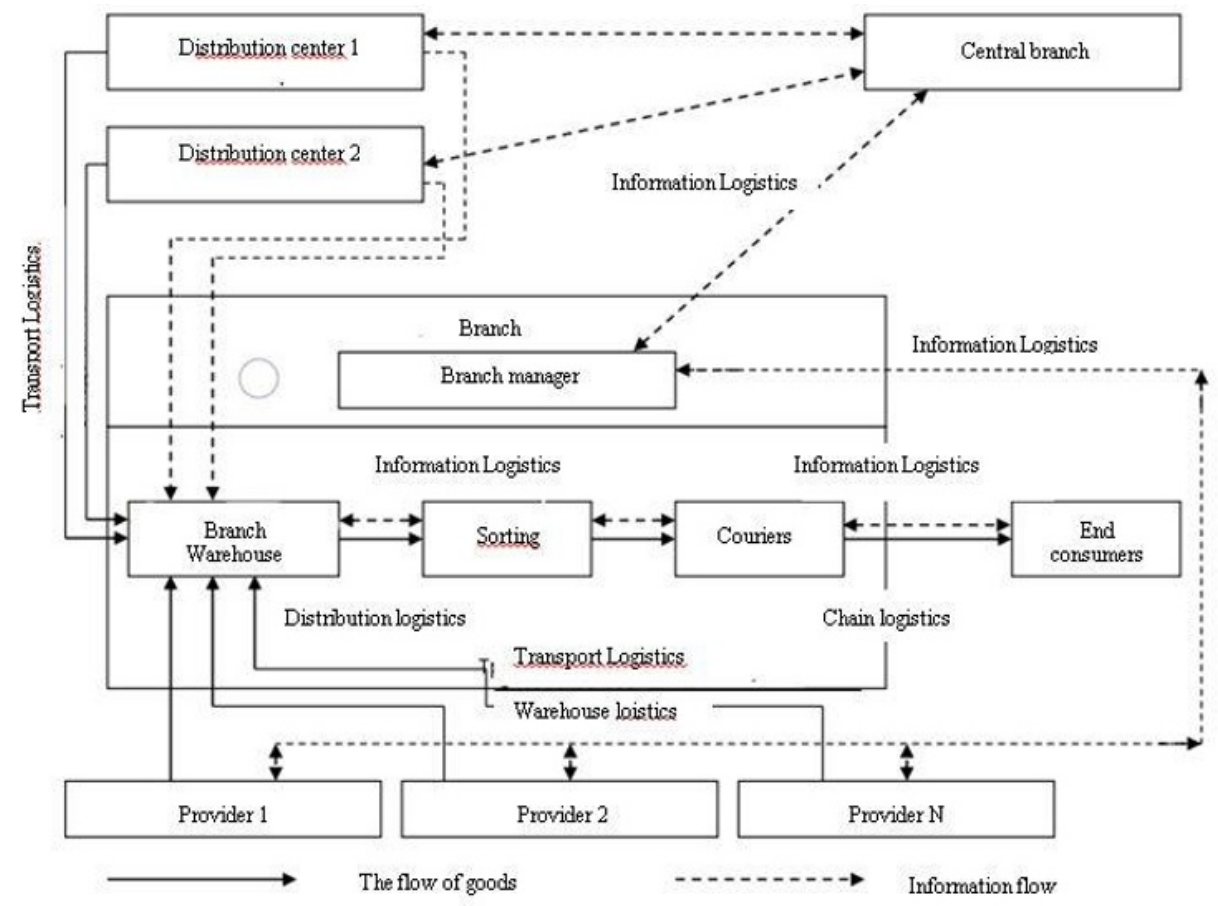

Fig. 1. Digital interaction of the information system of Delovye Linii LLC.
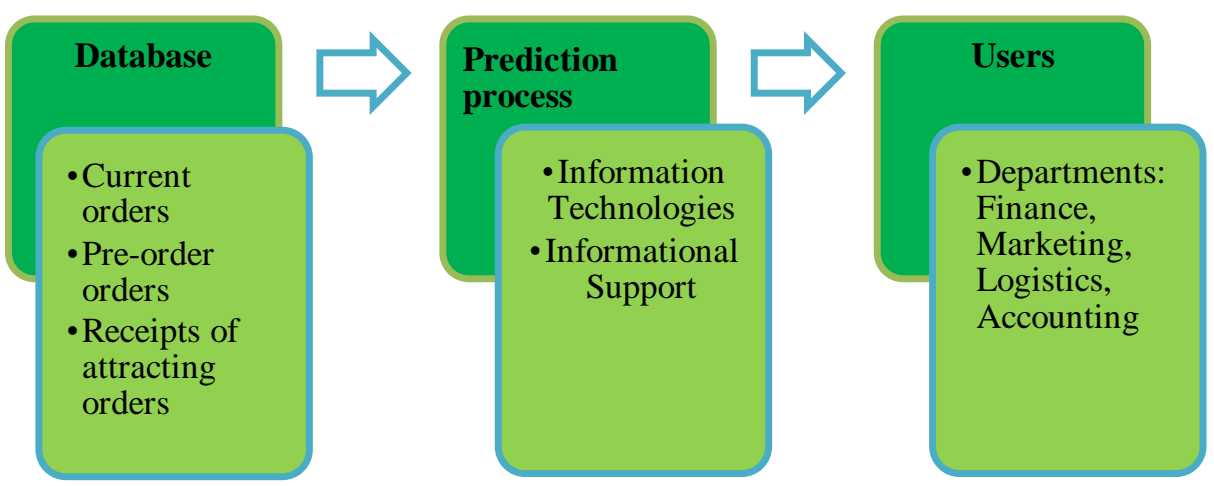

Fig. 2. Main components of the forecasting process in the supply chain of «Delovye Linii» LLC.

When considering potential suppliers and after analyzing the demand for goods, the purchasing manager of the central office forms an electronic order form in the information system, which is transmitted to the addressee via communication channels. After reviewing the order, the supplier forms an electronic confirmation of the order and transmits it to the center of responsibility. Such exchange of information significantly reduces time consumption and simplifies the transfer of messages. The use of information system allows 
to carry out orders accurately, on time, because wherever the supplier is, it is always possible to pass the message to him.

After the order is transferred, the supplier completes the batch of goods and according to the terms of the contract, delivers it to distribution centers or sends it to the warehouses of «Delovye Linii» LLC.

During the acceptance of goods in the database of the distribution center or warehouse, LLC «Delovye Linii» enters information about the incoming goods, their quantity and it is assigned a bar code. In the process of entering information about the goods in the database data on the status of the service is formed. This information may be used both by the storekeeper of the distribution center or warehouse, and by the purchasing manager of the responsibility center. After all, the information system of the warehouse is integrated with the information system of the central office and as a result a complex logistics information system of LLC «Business Lines» is formed. Thus, the joint work in the information systems of the storekeeper and the manager of the central office allows to organize the warehouse balances.

So, in the distribution center goods get only through the decision at the central office. The Responsibility Center is an administrative group that coordinates the work of the whole logistics chain of Delovye Linii LLC. There are information flows between the distribution center and the responsibility center, i.e. all orders for goods that come from the branches are processed at the central office and through them the order is made from manufacturers or suppliers. All goods that arrive at the distribution centers or directly at the branch warehouses are recorded in the database of the information system with the help of Rubicon software, which is integrated into my SAP EP. With the help of this software the central office can also control the balances both in the distribution centers and in the warehouses of Business Lines LLC. Therefore, all information flows are two-way [7].

Table 2. Information support for management processes of Delovye Linii LLC.

\begin{tabular}{|c|c|l|}
\hline $\begin{array}{c}\text { Automation object } \\
\text { Enterprise }\end{array}$ & $\begin{array}{c}\text { Type of information } \\
\text { technology }\end{array}$ & \multicolumn{1}{|c|}{$\begin{array}{c}\text { The impact of information } \\
\text { technology }\end{array}$} \\
\hline $\begin{array}{c}\text { Functions of the } \\
\text { enterprise }\end{array}$ & MRP & $\begin{array}{l}\text { Local automation of control } \\
\text { functions }\end{array}$ \\
\hline Processes & MRP-II & $\begin{array}{l}\text { Informational support of } \\
\text { integral management } \\
\text { functions and information } \\
\text { flows of separate } \\
\text { departments of the enterprise }\end{array}$ \\
\hline Enterprise & ERP & $\begin{array}{l}\text { Informational support of } \\
\text { integral management } \\
\text { contours and creation of a } \\
\text { unified information base of } \\
\text { the enterprise. }\end{array}$ \\
\hline
\end{tabular}

To manage information flows that arise in the process of promotion in the logistics system of LLC «Delovye Linii» we suggest using information technology class ERP. This choice is argued by the fact that ERP-class IT allows you to use one integrated program instead of several disparate ones, which provides the creation of a complete information space to automate the tasks of planning, accounting, control and analysis of all major logistics operations [1]. This applies primarily to the tasks of sales planning, demand studies, operational and accounting, procurement, inventory and sales management.

With the help of IT, ERP, it is possible to implement centralized data storage in a single database, bring the operating mode of Business Lines LLC closer to real time. Development 
of an effective logistics information system for the branch network is impossible without the use of special tools for modeling information flows.

For modeling information flows in the logistics system of LLC «Delovye Linii», we suggest using the family of IDEF tools (IDEF 0, IDEF 3, DFD).

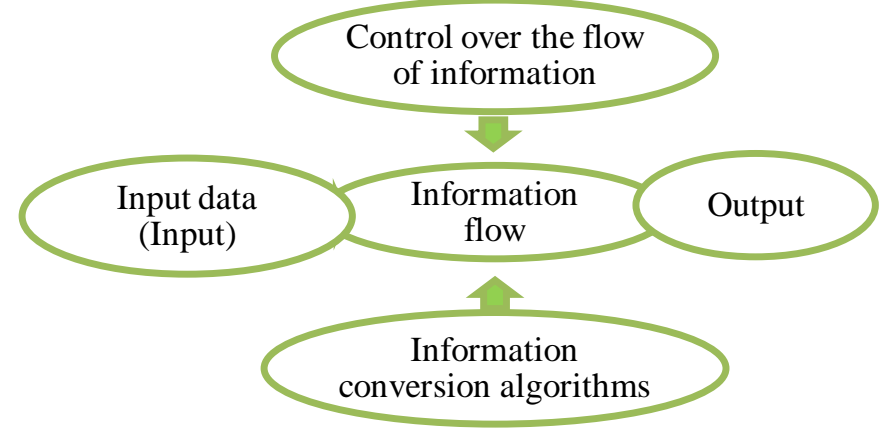

Fig. 3. Information flow model in IDEF software interpretation by Business Lines LLC.

This choice is based on the fact that it is thanks to these tools that it is possible to use a combination of graphical and language symbols and rules for fixing logistic processes and developing the structure of information flows. The use of IDEF family means allows to build a model of logistic system of «Delovye Linii» Ltd., which reflects the circulation of information flows. Diagrams, created in the process of modeling, contain concentrated information about logistic processes, through which not only translate and fix duties and functions of participants of logistic chain, but also define interaction between elements of organizational and functional structure of «Delovye Linii» LLC. At the same time, IDEF software allows to make it a language accessible for understanding of all interaction participants [6]. The use of IDEF tools allows to decompose complex logistic process into constituent parts (fig. 4).

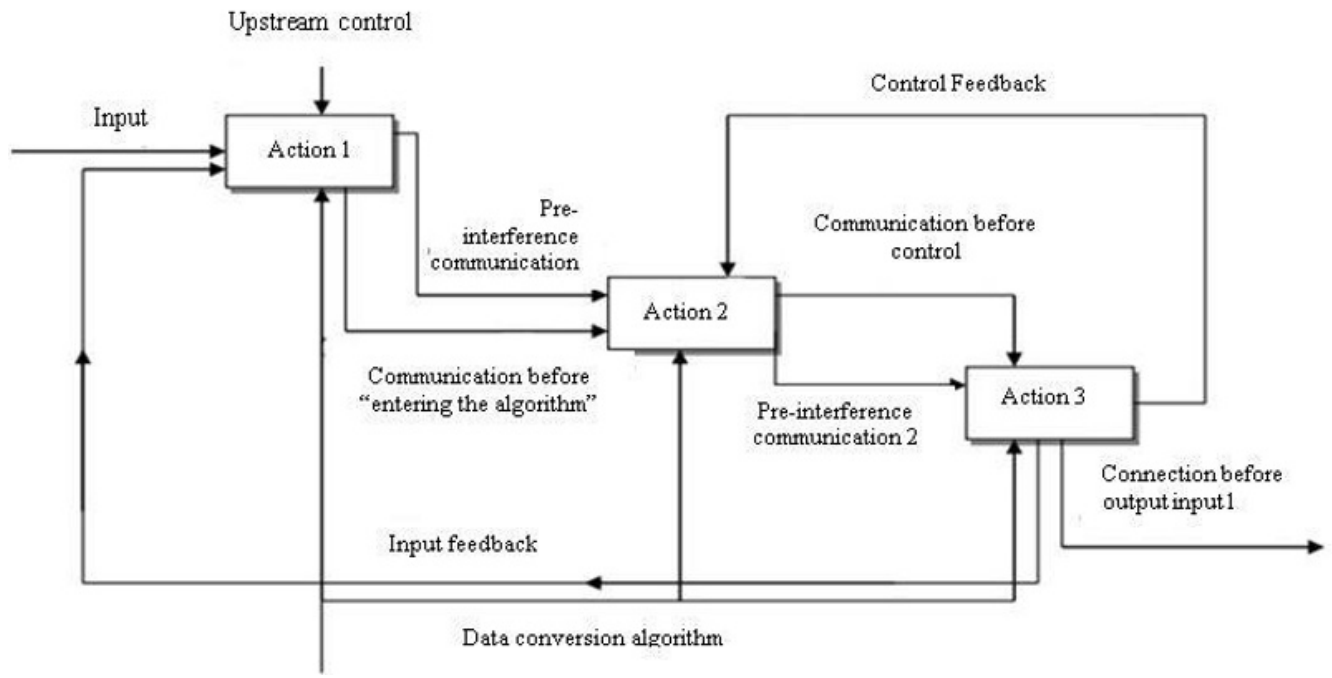

Fig. 4. Decomposition of information interaction in IDEF standard of Business Lines Ltd.

Creation of the logistic information system of «Delovye Linii» LLC through application of the SCM concept will ensure fast and correct information exchange between the participants of logistic chain. The proposed concept and the logistic information system 
created on its basis will allow to establish more efficient activity of «Delovye Linii» LLC and get rid of the Bullwhip effect.

\section{Conclusion}

The integration of digital technologies will create new prospects for the transport business. They will help to modernize the company and provide new sources of value for customers, as well as create new revenue generating opportunities. Therefore any business should be interested in digitalization. Of course, it is very important to have a strategic approach to digitalization. This option will ensure the coherence of digital activities by consolidating and harmonizing all digital efforts to achieve the goals of Business Lines LLC. This ongoing process, which includes the creation and implementation of a digital strategy, is today critical to the future success of any organization.

The use of IDEF methodology and ERP class information technology allows to take into account the specifics of a complex distributed economic system of «Business Lines» Ltd. and to solve various tasks of information flow management. Use of SCM concept will allow to manage information and material flows transparently and to react quickly to changes in internal and external environment of logistic information system.

\section{References}

1. Belov N I, Chabanova E V 2020 Collection of articles of II All-Russian scientificpractical conference (Kazan) p 9

2. Zaitseva O, Samsonova O 2019 Collection: International scientific student readings. Materials of the XVI International Scientific Student Conference 277

3. Kravchenko L A, Fursova E A 2020 Journal of economic research 6(3) 47

4. Mashkina N A, Veliev A E 2020 CITISE 1(23) 290

5. Mezhokh Z P, Yurkovskaya E P 2019 Conceptual problems of economy and management on transport: a look into the future. Proceedings of the International Scientific and Practical Conference 199

6. Milyaeva E A 2020 Artificial intelligence and digital economy: a view of students (Moscow) 107

7. Official website of the company Delovye Linii LLC https://www.dellin.ru/company/ 